\title{
Teaching Graduate Accounting Students What They Need To Know About Marketing Their Profession
}

Donna J. Hill, Bradley University, USA

Shondra Johnson, Bradley University, USA

\begin{abstract}
This paper describes a graduate professional services marketing class which focuses on experiential learning in the context of the accounting profession. It incorporates traditional services marketing theory with development of critical marketing skills as identified by practicing professionals. Ten to fifteen years ago, professional services marketing courses emerged and several pedagogical papers were published (Blanchette, 1996; Gremler, Hoffman, Keaveney \& Wright, 2000; McNeilly \& Bar, 2001). However, compelling changes in professional practice and the economic climate have significantly impacted the accountant, resulting in the need to understand a new generation of marketing skills. Emphasis is placed on the role and importance of trust, interpersonal relationships, and understanding of the market and client. Students form "firms" that compete in a structured project where they research the potential client, write a formal response to a proposal, make presentations, and compete with each other for a new client engagement. Included are learning objectives (outcomes), detailed descriptions of instructional exercises, suggested readings and student assessment recommendations.
\end{abstract}

Keywords: Professional Services; Marketing; Accounting; Proposal

\section{INTRODUCTION}

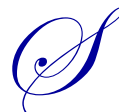

ervice professionals have experienced significant change stemming from the economic recession that started in 2008. Companies faced with cost-cutting initiatives have cut professional services or pressured providers to reduce service fees. Professional service firms have responded to this economic reality by implementing such tactics as value pricing, launching social media efforts, and implementing more customer satisfaction programs (Baker, 2009; Bildstein, 2010; Andrew, 2011). For example, a 2011 survey conducted by the American Institute of Certified Public Accountants highlights the impact of the economy by reporting that a top issue common to all firm sizes is growth, with bringing in new clients and retaining current clients ranking high in importance (American Institute of Certified Public Accountants, 2011). More recently the 2013 Private Companies Practice Section (PCPS) CPA Firm Top Issues survey noted that accounting firms are pursuing new clients with vigor (Drew, 2013).

In response to these and other developments, we propose a contemporary marketing course intended for master-level students entering a profession. Service professionals experience unique marketing challenges. Primary among these is the need for the professional to market their knowledge, capabilities and skills, which form the basis of their market offer. Because the knowledge and skills of service professionals are the product; personal integrity, responsiveness, credentials, experience levels, personalities, communication skills, service attitudes, and other characteristics of the professional are critical attributes sought by the client (Stanny, Anderson, \& Nowak, 2000). Challenges include the ever-changing relationship with a client, commoditization of services, emergence of electronic marketing mediums, and the growth of global competition.

To initiate our course development, we conducted interviews of managers and partners of accounting firms. These key informants represented firms of all sizes and provided the marketing insights which, in turn, influenced 
the instructional design of the graduate course. In addition, these key informants highlighted the role of trust in the professional's relationship with clients. For instance, referral sources for new work often include attorneys, bankers, insurance agents and existing clients who already have a sense of trust. Attorneys are particularly lucrative referral sources (Drew, 2013). One informant asserted that when formal proposals are needed, it is important to demonstrate rather than assert and to illustrate rather than tell. According to one director interviewed, "Everything turns to marketing." Each professional commented how much they wish they could have taken a services marketing course to propel their career.

Table 1: Process of Developing the Course

(Each element needs to align with the overall marketing strategy of the organization)

\begin{tabular}{|c|c|c|c|}
\hline Interview Topics & Marketing Insights & Instructional Design & Learning Outcomes \\
\hline $\begin{array}{l}\text { Personal success } \\
\text { within a service } \\
\text { firm }\end{array}$ & $\begin{array}{l}\text { - What it means to be a } \\
\text { professional } \\
\text { - Taking charge of career } \\
\text { - Personal plan for professional } \\
\text { development } \\
\text { - Importance of trust, } \\
\text { independence and self } \\
\text { confidence }\end{array}$ & $\begin{array}{l}\text { - Read published articles } \\
\text { regarding professionalism } \\
\text { (Stage One) } \\
\text { - Observe and analyze service } \\
\text { scape of a professional } \\
\text { environment (Stage Two) }\end{array}$ & $\begin{array}{l}\text { - Identify expectations of clients } \\
\text { and a firm's owners } \\
\text { - Show ability to work with a } \\
\text { team of service professionals }\end{array}$ \\
\hline $\begin{array}{l}\text { Influences } \\
\text { leading to } \\
\text { requests for new } \\
\text { services }\end{array}$ & $\begin{array}{l}\text { - Professional associations } \\
\text { - Firm name/brand } \\
\text { - Nonprofit affiliations } \\
\text { - Community organizations } \\
\text { - Chamber of commerce } \\
\text { - Volunteer activities }\end{array}$ & $\begin{array}{l}\text { - Personal marketing plan } \\
\text { (Stage Two) } \\
\text { - Evaluate professional service } \\
\text { advertisements (Stage Two) } \\
\text { - Scrutinize websites of service } \\
\text { providers (Stage Two) }\end{array}$ & $\begin{array}{l}\text { - Demonstrate ability to prepare } \\
\text { an appropriate personal plan } \\
\text { - Evaluate community } \\
\text { opportunities consistent with } \\
\text { personal interests } \\
\text { - Demonstrate understanding of } \\
\text { communication guidelines }\end{array}$ \\
\hline $\begin{array}{l}\text { Requests for new } \\
\text { services }\end{array}$ & $\begin{array}{l}\text { - Solicitations } \\
\text { - Mail / advertising } \\
\text { - Word of mouth } \\
\text { - Social media }\end{array}$ & $\begin{array}{l}\text { - Qualification package (Stage } \\
\text { Two) }\end{array}$ & $\begin{array}{l}\text { - Form an example firm } \\
\text { - Design and structure their } \\
\text { firm's qualification package }\end{array}$ \\
\hline $\begin{array}{l}\text { Responding to a } \\
\text { request for } \\
\text { proposal (RFP) }\end{array}$ & $\begin{array}{l}\text { - Not if the industry is } \\
\text { unfamiliar, } \\
\text { - or if realization/ profitability } \\
\text { will be low, } \\
\text { - or if the financial health of the } \\
\text { potential client is low }\end{array}$ & $\begin{array}{l}\text { - New client evaluation } \\
\text { process (Stage Three) } \\
\text { - Determining fees (Stage } \\
\text { Three) } \\
\text { - Proposing new services } \\
\text { (Stage Four) } \\
\end{array}$ & $\begin{array}{l}\text { - Research strengths and } \\
\text { weaknesses of a potential } \\
\text { client } \\
\text { - Complete background checks } \\
\text { of key persons } \\
\text { - Prepare and present proposal }\end{array}$ \\
\hline $\begin{array}{l}\text { Persuasive factors } \\
\text { for selection by a } \\
\text { new client }\end{array}$ & $\begin{array}{l}\text { - Responsiveness and thinking } \\
\text { proactively } \\
\text { - Industry insight and } \\
\text { understanding the client } \\
\text { - Size of firm } \\
\end{array}$ & $\begin{array}{l}\text { - Research the needs of an } \\
\text { organization (Stage Three) } \\
\text { - Apply technical } \\
\text { competencies (Stage Three) }\end{array}$ & $\begin{array}{l}\text { - Identify current issues facing a } \\
\text { potential client } \\
\text { - Pose investigative questions to } \\
\text { key client personnel }\end{array}$ \\
\hline Client satisfaction & $\begin{array}{l}\text { - Challenge to get feedback } \\
\text { - Becoming a trusted business } \\
\text { advisor }\end{array}$ & $\begin{array}{l}\text { - Examine examples of client } \\
\text { satisfaction surveys (Stage } \\
\text { Four) }\end{array}$ & $\begin{array}{l}\text { - Design client satisfaction } \\
\text { survey }\end{array}$ \\
\hline
\end{tabular}

Table 1 shows the process of developing this course and includes topics discussed when meeting with industry representatives. As a result of their insights, experiential exercises were developed. We defined learning outcomes based on those exercises. Although for this paper we used an accounting firm example, this same process could be adapted to develop customized marketing instruction for other service professionals including attorneys, physicians, management consultants, engineers, architects and others requiring graduate degrees.

Using elements from Table 1, which describes the process of developing the course, we integrated the service marketing discipline and the public accounting setting. Figure 1 shows a conceptual framework for the four stages of the course when applying experiential learning. The first three stages consist of understanding marketing strategy, marketing tactics for growth, and responding to proposals. The fourth stage involves presentations of proposals, the acceptance process, and client satisfaction. This figure helped students conceptualize the course and navigate as it progressed. 


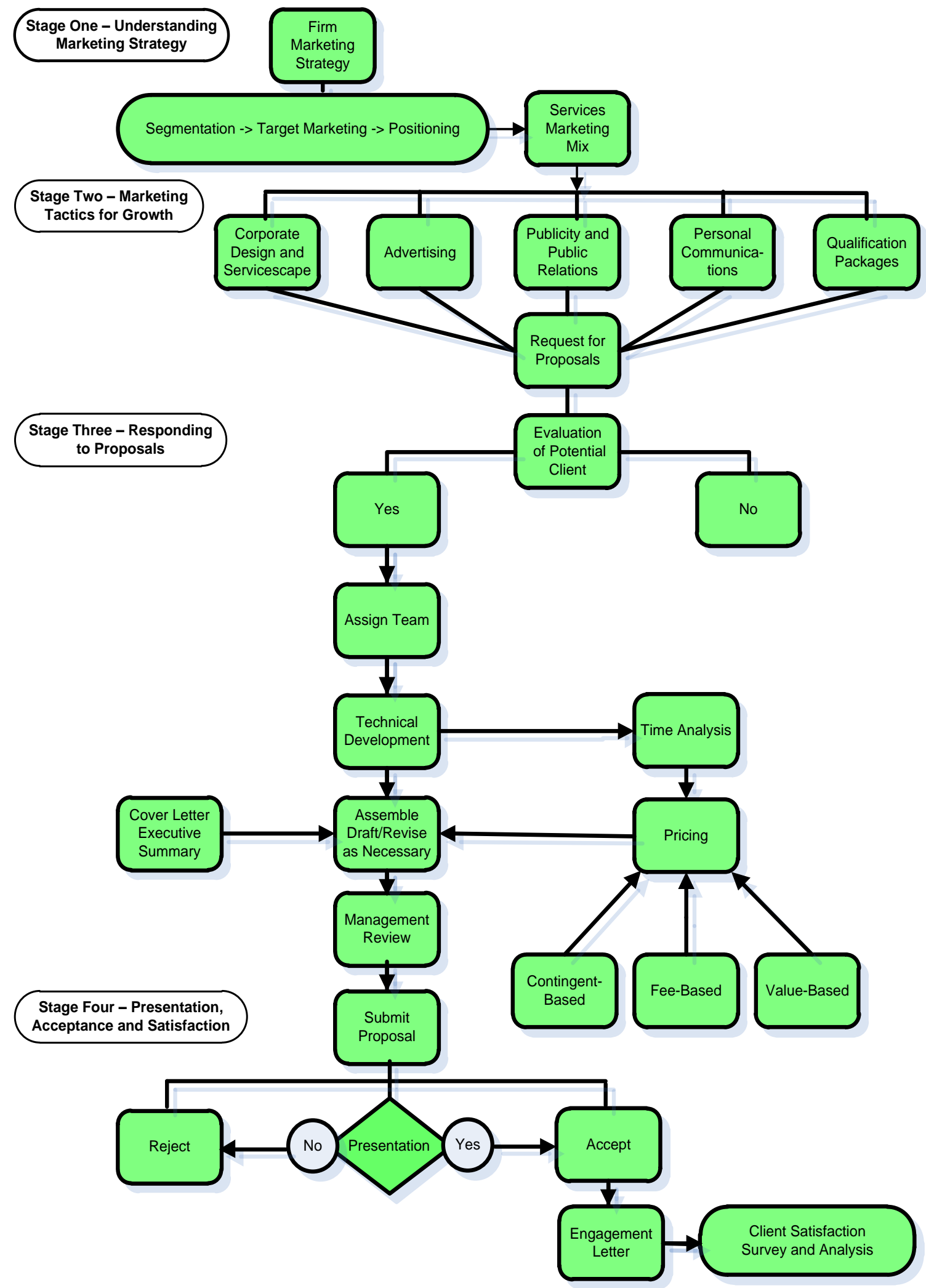

Figure 1: Framework for Development of Experiential Learning 


\section{COURSE OUTLINE AND OVERVIEW}

The marketing function of most professional firms involves first developing an overall marketing strategy, which includes services to be offered, mission statement, market segmentation, targets served, positioning, and the firm's service marketing mix. It is important to show participants the basic business model of professional firms, while sharing the issues related to being a professional. This part of the course is Stage One. With this basic understanding participants can then appreciate the role of the services marketing mix: product, place, promotion or communication, price, people, physical evidence, and process. While some emphasis is placed on each element of the mix, more time should be spent on those elements most relevant to the professional service for which the course is designed. For accounting firms, communication mix is generally designed to illicit requests for proposals, representing Stage Two of the course. Once requests for proposals are received by the firm, a process begins that may lead to an engagement and firm growth. Responding to proposals involves technical, research, presentation and, importantly, interpersonal skills on behalf of the professional. Estimating fees is also a significant part of developing a proposal. This completes Stage Three of the course. The final and last stage, Stage Four, requires students to present their written proposals to a selection committee and provide any follow-up needed.

An example request for proposal (RFP) from the American Red Cross was used as a basis for the experiential approach adopted in our course. See Table 7 for the example we developed for the course. We chose the American Red Cross because information about the organization is readily available online and in press releases. The RFP represented a letter from the American Red Cross to the student-member accounting firm requesting a proposal. The background of the American Red Cross, along with a description of services needed from the accounting firm, contact names at the American Red Cross, a list of specific information requested and description of the evaluation process was included. An electronic copy of the RFP may be obtained by contacting one of the authors. Other RFPs could be developed or a local organization may provide an RFP. The subsequent sections provide greater detail for each stage of the course, along with examples of assignments and suggested readings.

\section{Stage One - Marketing Strategy \\ Professional Services Marketing}

The course opens with a discussion of what it is to be a professional and how becoming a professional will impact a person's career and life. The basic definition of a professional (for a good description see Gummesson, 1981) is presented and participants read the article "Once We Had Professionals" by Campbell (2002). This article discusses the view of the professional, including the professional's role as an expert, and the importance of trust, independence, and self-confidence. Material from Maister (1997) supports this discussion. Independence rules restrict the nature of services that may be provided to clients. This situation complicates the marketing process because certain advisory services are off limits, even if desired by the client.

A related issue is becoming a successful professional within one's firm. To be a professional one needs to approach his/her career with a mind toward life-long learning. All service professionals should develop expertise or their skills will become less valuable. Newly hired professionals need to persuade partners to give them the work that best develops their skill sets. Such persuasion works well when the new hire takes charge of his/her own career and demonstrates a good work ethic (Latta, 2004). "New hires" in an accounting firm need to position themselves as the go-to person. This translates into building idiosyncratic credit. The adoption of a personal marketing plan for professional development by the second year of employment is essential for career success (Zdunich, 2010).

This naturally leads into the nature and characteristics of services compared to goods as well as the role of professional services within the services marketing paradigm. A brief review of the characteristics of intangibility, perishability, inseparability, and variability and their impact on marketing a professional service are discussed and examples of their implications presented. These concepts re-appear throughout the course and should be thoroughly covered. Many exercises are available to convey these concepts (see Wisenblit, 1994; Gremler, Hoffman, Keaveney \& Wright, 2000). A chapter or two from a services marketing text (Clow \& Kurtz, 2004; Lovelock \& Wirtz, 2011; Zeithaml, Bitner, \& Gremler, 2009) could be assigned. 
Marketing Strategy: Segmentation, Target Marketing, and Positioning

Market segmentation represents the process of dividing the market into homogeneous groups of customers who respond similarly to a market offer. According to Kotler, Hayes and Bloom (2002), marketing strategy is the selection of target markets, the choice of positioning, and the marketing mix aimed at the chosen clients. While segmentation variables depend on the specific professional service; typical ones used in accounting include industry, countries of operation, readiness for consulting or auditing, company size, or specific emerging issues. It is important to analyze the specific needs of each market segment.

Selecting the appropriate target market or markets is frequently the most important decision a company makes in the strategic planning process; and should be made only after careful consideration of, among other things, firm resources and capabilities measured against sales, costs, and profits. Critically tied to growth and business development are nich services (Drew, 2013; Zenger, 2013). Many accounting graduate students have not been exposed to the various types of targeting options: mass marketing, focused (target) marketing, niche marketing, and micro marketing. Therefore, a good assignment is to require each participant to examine market coverage by finding and defending an exemplar of each targeting option in the professional arena. The course discussion leader may wish to share examples of professional service firms with a highly niched orientation, such as Kenneth Leventhal \& Co. (Real Estate), Oppenheimer \& Co. Inc. (Investments) and Ernst \& Young (Healthcare). Discussion can include which types of firm participants would feel comfortable working for both in the short and long term. Articles by Caragher (2008) and Lowry and Wrege (1996) present the role of niche marketing versus mass marketing.

An important concept in professional services marketing strategy is growth options (Andrew, 2001; Young, 2005). A firm that grows is better able to serve additional needs of existing clients, while attracting new clients with similar needs. Growth adds depth to expertise for an accounting firm. In addition, growth attracts and adds highly qualified professionals to the firm. It is important to note that the Sarbanes-Oxley Act of 2002 places limits on services that can be legally provided to public companies, which are also audit clients. In particular, auditors of public companies are prohibited from performing any accounting or bookkeeping services as it would threaten CPA independence. Consulting activities are also not allowed. Additional guidance regarding independence for nonpublic clients is provided in the AICPA Code of Professional Conduct. CPAs may assist a nonpublic client by providing research materials and recommendations so long as management functions are not performed.

An equally important concept in marketing strategy is competitive advantage and positioning. A firm's market position is the way the organization is perceived by the market relative to competing firms. For example, Grant Thornton International claims to provide, "a more personalized service and better value for money." Deloitte says "we understand the issues." PricewaterhouseCoopers represents itself as the "major international accounting and consulting firm." Participants can explore positioning by creating a positioning map for a group of firms in a specialized industry such as insurance. This emphasizes for the student the relationship of positioning to overall marketing strategy. For a good overview article on a strategic planning approach for an accounting firm see Shepherd (1997).

\section{Business Operations of a Service Firm}

Developing a solid proposal for profitable, new and recurring professional services requires an ability to understand the basic business model of an accounting firm. We suggest devoting a meeting or two to this topic early in the program. The core of this discussion involves the net amount of earnings for partners (i.e. distributable income to the partners). Participants should learn that accounting firms typically organize as partnerships. And as employees of an accounting firm, students are responsible for contributing to the net earnings for partners. This means that accounting professionals experience accountability for their time. In a service business, employees are the machinery of production. According to Latta (2004, p. 17), if professionals "are off-line or not as productive as possible your employer suffers the consequences."

Table 2, which should be shared with participants, shows how a typical accounting firm arrives at net earnings for partners. Revenues reduced by expenses yields net earnings. While many business organizations would call this result net income, an accounting firm recognizes that the result represents earnings available for partners. 
Such wording reflects the need for new hires to be accountable for their time at work. According to Latta (2004, p. 66), "The art of time management is important to everyone, but as professionals the need to master it is in front of us all the time."

Table 2: Net Remaining For Owners

(Amounts shown in thousands)

\begin{tabular}{|c|c|c|c|}
\hline & Small IL Firms & Medium IL Firms & Large IL Firms \\
\hline Gross fees earned & 166,870 & 601,825 & $2,300,864$ \\
\hline Net write-ups/downs & $-5,287$ & $-14,532$ & $-321,507$ \\
\hline Net revenue (fees) & $1 \overline{161,583}$ & 587,293 & $1,979,357$ \\
\hline Other revenue & 527 & $\underline{5,916}$ & 12,036 \\
\hline Total revenue & $162, \overline{110}$ & $59 \overline{3,209}$ & $1,9 \overline{1,393}$ \\
\hline Write downs as \% of Gross & $-3.2 \%$ & $-2.4 \%$ & $-14.0 \%$ \\
\hline Net client fees per FTE & 116,390 & 207,642 & 154,971 \\
\hline Professional salaries, excl. owners & 13,340 & 86,100 & 602,470 \\
\hline Paraprofessional salaries & 13,718 & 35,334 & 63,905 \\
\hline Other salaries, excl. partners & 4,371 & 19,508 & 68,765 \\
\hline Retirement plan costs, excl. owners & 809 & 4,676 & 28,265 \\
\hline EE benefits, excl. owners & 3,433 & 7,684 & 58,212 \\
\hline Dues, library & 1,758 & 6,305 & 17,085 \\
\hline Continuing professional education & 903 & 3,765 & 6,510 \\
\hline Malpractice insurance & 1,077 & 4,114 & 14,233 \\
\hline Rent and other occupancy costs & 12,959 & 42,686 & 115,019 \\
\hline Computer and technology & 5,443 & 11,855 & 35,439 \\
\hline Promotion and marketing & 1,679 & 7,724 & 31,053 \\
\hline Payroll taxes & 5,048 & 16,129 & 79,836 \\
\hline Phone and web connectivity & 2,515 & 6,319 & 12,189 \\
\hline Depreciation & 1,441 & 8,401 & 23,404 \\
\hline Other expenses & 17,449 & 53,915 & 167,261 \\
\hline Total expenses & 85,942 & $\underline{314,517}$ & $1,323,646$ \\
\hline Net remaining for owners & 76,168 & 278,691 & 667,747 \\
\hline Owner FTE & 1.07 & 1.29 & 3.31 \\
\hline Net revenue per owner & 151,012 & 456,784 & 598,410 \\
\hline Income per owner & 71,090 & 216,760 & 201,877 \\
\hline Income per hour per owner & 33.96 & 87.87 & 83.23 \\
\hline Average realization & $47.1 \%$ & $47.4 \%$ & $33.7 \%$ \\
\hline
\end{tabular}

Source: PCPS/TSCPA 2008 National MAP Survey. http://www7.intellisurvey.com/run/map10home

To manage an accounting firm towards higher earnings, partners typically focus on five financial indicators. These indicators include utilization percentages, accounts receivable balances, amounts of unbilled work, realization percentages and working capital. Of these indicators, utilization (billable hours / total hours worked) and realization (revenues reduced by expenses / net revenues) are fundamental to a firm's financial health because they speak to productivity and then profitability. Utilization for medium-sized firms, for example, averages more than seventy percent. Increasing utilization happens when professionals work harder but not necessarily when they work more efficiently. Therefore, utilization yields short-term results.

Professionals may "eat" hours by not reporting them. For instance, when a firm negotiates a fixed fee, compared to an hourly fee, eating hours to achieve higher utilization is more attractive. This often creates unrealistic subsequent time budgets and is not appropriate because such short-term results cannot be repeated. Many firms have policies against eating hours, and violation may result in termination. Increases in realization, achieving a higher value on each hour worked, are greater accomplishments than increases in utilization. 
Table 2 illustrates the difference in realization by firm size and highlights the reality that large firms are not always the most profitable per partner. A student with insight to these financial indicators may be more likely to achieve long-term professional success. In summary, learning the business model of the firm will help students become aware that their personal career goals must support their employers' financial goals.

\section{Stage Two - Marketing Tactics for Growth}

Stage Two focuses on the communication tactics most frequently and most effectively used to generate new clients and growth. According to Lovelock and Wirtz (2011), the service communication mix consists of the following channels: personal communications, advertising, sales promotion, publicity and public relations, instructional materials, and corporate design. Table 3 outlines these channels, along with marketing tactics most effective for professional services. Since referrals and image (i.e. brand reputation) are still the top ways clients identify providers of professional services (Schultz \& Doerr, 2009), we focus on personal communications, advertising, corporate design and servicescape, public relations, and qualification packages, which are critical to generating client contact.

Before discussing specific tactics, start with a broad overview of the communication function as well as the tools most commonly used by professional service firms. Illustrate examples from advertising of the common guidelines for services promotion: 1) promising what is possible, 2) making the intangible tangible (address service intangibility), 3) reducing client risk perceptions, 4) managing service promises, and 5) recognizing the relationship between staff and clients (Mittal, 1999; Hill \& Gandhi, 1992; Berry \& Clark, 1986). Furthermore, these guidelines need to cross all elements of the marketing communication mix to create an integrated approach.

Table 3: Communication Mix Types

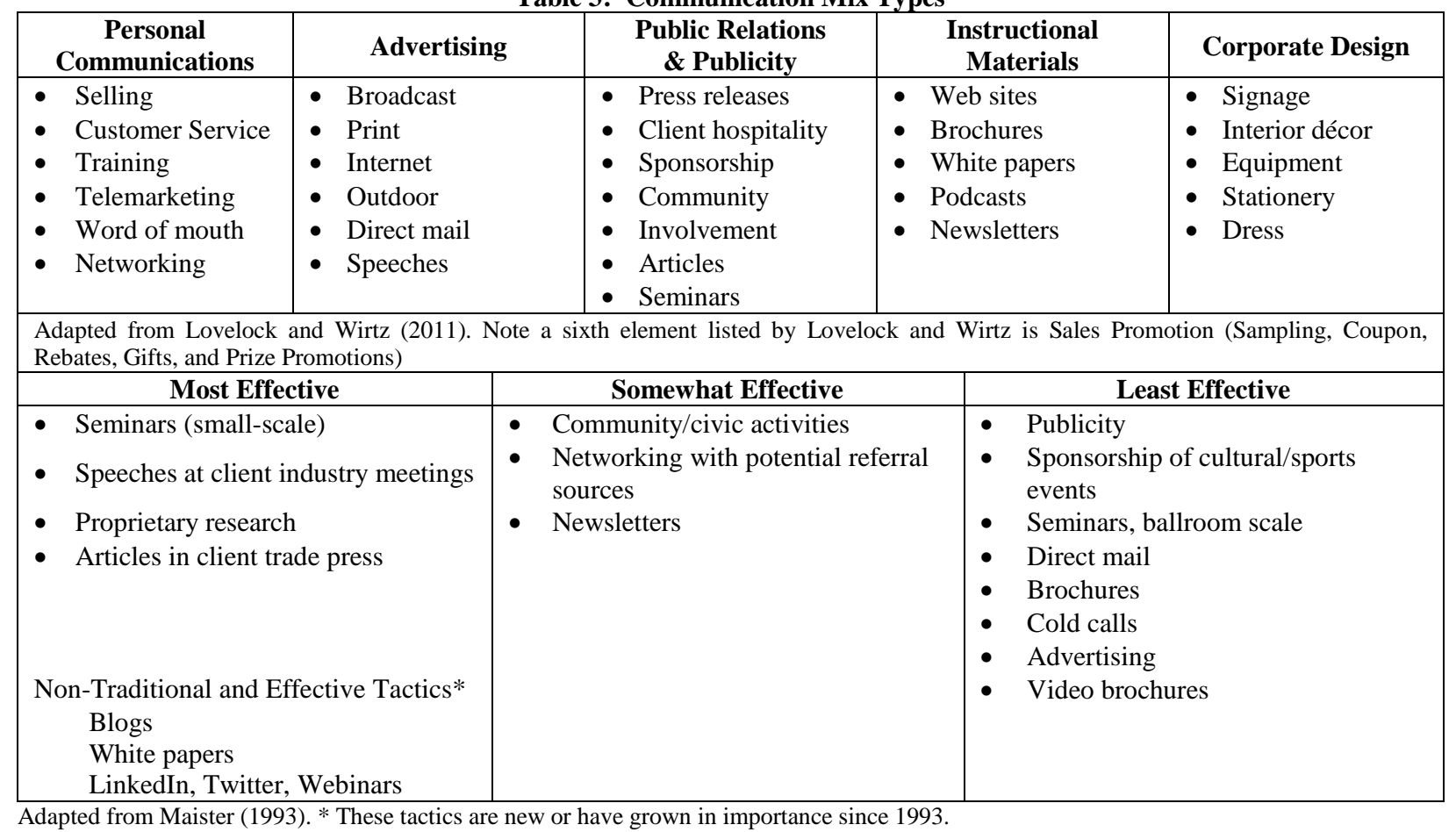

\section{Corporate Design and Servicescape}

The servicescape or physical elements of the firm represents a good place to start discussion of the communication mix and is a part of what Lovelock and Wirtz (2011) refer to as corporate design. Ask participants to pretend that, due to an emergency, they use an unknown dentist. Participants often express apprehension about engaging that service provider. What clues would they rely on to make their decision? The transition can then be 
quickly made to other professionals including an accounting firm. The role of professional dress and office location/atmosphere and its impression on potential clients should be emphasized. Accounting firms emphasize the importance of professional dress by requirement. Dress codes frequently address business casual attire, tattoos and body piercing, as well as a plan of action for violations. The Berry and Bendapudi (2003) article makes a great reading assignment about how the Mayo Clinic manages its servicescape and generates considerable additional discussion. Contact one of the authors for an example dress code or a servicescape assignment.

\section{Advertising}

Advertising is often the first contact point between service professionals and their clients and builds awareness, informs, persuades, and reminds. This topic warrants a minimum of two course sessions. Advertising approaches for professional services vary greatly depending on a number of factors including size of the firm, the targeted industries or segments, economic conditions, and growth objectives. Many small and midsize firms limit advertising activities to their Website and Yellow Pages. Larger firms typically expend a great deal on advertising as it is used extensively to build image, brand awareness and reputation. While advertising typically appears least effective when generating business, it plays a major role in projecting an appropriate image, promoting the brand promise, reminding clients about the service, and differentiating the professional service in the minds of clients. Although the field of social media marketing is changing quickly and the reader will want to check for more current material, three short articles from the Journal of Accountancy ("How to Leverage Social Networking," 2009; Pinkston, 2009; Bonner, 2009) provide discussion material using this medium.

Evaluating advertisements gives participants insights into how firms engage in advertising. Current print and video ads (see Wall Street Journal, Business Week, Fortune, and YouTube links or company websites) are easily identified. Additionally, webcasts and podcasts are becoming extensively used by larger firms. For example, Deloitte offers podcasts (www.deloitte.com) regarding provoking topics via iTunes. Communication guidelines as well as the target audience, the positioning and brand promise execution can all be assessed. Websites represent another medium of promotion. Firm websites should be coordinated in theme, content and brand promises with all other communications including advertising. Most accounting firms, such as KPMG, Ernst \&Young, PricewaterhouseCoopers, include client testimonials on their websites. Client testimonials are an extraordinarily effective marketing strategy particularly if they are perceived as believable, include specific examples of how the client benefited from the service and highlight the service provider's discriminators (Garikes \& Roch, 2008). Client testimonials and client lists help to effectively establish credibility and reputation for the firm. Readings covering aspects that make for effective accounting firm websites and the items commonly found in them should be assigned (Louwers, Pasewark, \& Typpo, 1999; Stimpson, 2007). Contact one of the authors for an example web assignment.

\section{Publicity and Public Relations}

Public relation activities support and extend the advertising/website message and play a critical role in most professional practices; it may communicate a broad-based knowledge of a firm and its skills while building credibility. The primary strategy of public relations is to "give away" a portion of the professional's expertise (Drochlich 1995). In this manner the value of the firm's services and the expertise of the professional are demonstrated. Seminars, speeches at client industry meetings, proprietary research, and articles targeting prospective clients build personal recognition or awareness of the provider while enhancing trust. Additionally, most professional service firms become involved in community and professional organizations as well as sponsorships and social cause marketing. Chapter 11 of Maister (1993) could be assigned as reading to emphasize the importance of public relations in the life of the professional.

\section{Personal Communications}

Two critical elements of the personal communication tactics is personal business generation (selling) and other direct contact with clients. Most new clients originate from long-standing relationships with key management or board members and subsequent referrals; therefore participants need to appreciate the importance of personal communication. Whether playing a supporting or lead role, accountants must participate in three activities. 1) Contacting and obtaining additional revenue from existing and prospective clients through discussion and 
identification of needs. 2) Retaining endangered revenue with clients who may be thinking of ending their relationship with the firm. 3) Obtaining referrals and leads from satisfied clients and targets of influence such as bankers and attorneys. This translates to "serving the heck out of the client you have" because every client relationship is endangered if they do not receive the best every day.

"Professional firms sell their services in any number of ways, but virtually all of them start with reputation" (Latta, 2009, p. 92). As a result of the problems Arthur Andersen experienced with a few clients (Enron, MCI and others), a stain tainted the reputation of the entire organization and ultimately destroyed it. Intangible services (i.e. forecasting or performing reviews) compared to tangible services (i.e. tax return) are even more reliant on reputation and trust. Reputation and personal marketing "is about participating in the life of the community, whether that community is a city, an industry, or simply a network of business associates. And it is about being known" (Latta, 2009, p. 94).

Conceptualizing, developing and implementing a personal marketing plan are critical to a successful accounting career. A personal marketing plan is a document that outlines external communication strategy, identifies objectives and activities for career development and positions one within the firm. Other elements of the personal marketing plan include community involvement, involvement with professional associations, speaking opportunities, and other activities to make one known within the firm. Differentiation and setting oneself apart is essential in a competitive marketplace. Suggested by and adapted from Young (2005) each student is required to prepare and present this document. This activity helps students realize they are not homogeneous employees. Internally, ways to become known and positioned within a firm include networking and volunteering to serve supporting roles such as developing group online materials, writing articles about clients and researching information for engagement proposals. Externally, for the young professional the importance of becoming active in the community and professional organizations is not always apparent. This assignment galvanizes a student's understanding of the expectations placed on accounting professionals.

By highlighting the importance of giving these networking activities high priority the new professional is in a better position to quickly leverage their career. The importance of matching the skills, interests and values with each of these should be emphasized to the student. A guest speaker with at least five years of professional services experience gives relevance to the importance of both components. Students should have prepared their personal marketing plan before the guest speaker visits. See Table 4 for the student's assignment regarding a personal marketing plan. The directions require a personal mission statement and determination of goals. The directions also require the participant to identify what makes the participant unique from other accounting professionals and develop marketing tactics. 
Table 4: Personal Marketing Plan

Personal marketing is about how to become recognized as an expert in your chosen area. In turn, your reputation and knowledge will convince clients and directors to seek you out when they are in need of your services. This document should include your career objective as well specific tactics to achieve those objectives.

1. Your Mission statement or "Your Reason for Existence"

2. Your Objectives and Goals. Goals should be outlined in terms of short (1 to 3 years) and long term (4 to 7 years). The focus of the first 3 years or so is to get involved in your firm and get known. Longer term goals focus on being recognized as $n$ expert in a specific area.

3. Target a Specific Audience. Select one or two groups to target with your marketing efforts. Analyze the characteristics of your best prospects; other groups with similar qualities may be the best place to start. Characteristics might be industry, size, location, etc. Again, what you are interested in is who are they, where do they go to learn, what do they read, watch and listen to, what conferences do they attend, what activities are they involved in.

4. Differentiation. What makes you unique? Setting yourself apart from other accounting professionals is essential in a crowded marketplace. Remember, clients choose services based on the benefits and value to their firm. Make sure you outline your strengths and weakness. You should focus on your strengths and plan how to mitigate or accommodate your weaknesses into your overall career. Possible points of differentiation are:

- $\quad$ Education - law degree, CPA, etc.

- A specialist in a particular industry or service area.

- Technical expertise.

- Responsiveness and commitment to client.

5. Outline Your Marketing Tactics to Build on your strengths and mitigate your weaknesses. Remember Personal Marketing Tactics include but are not limited to the following:

$\begin{array}{lll}\text { Speeches at client industry meetings } & \text { Seminars } & \text { Newsletters } \\ \text { Speeches at client conferences } & \text { Publicity } & \text { Blogs } \\ \text { Articles in client-oriented (trade) press } & \text { White Papers } & \text { Personal Selling } \\ \text { Networking with potential referral sources } & \text { Firm Web Site } & \text { LinkedIn and Twitter } \\ \text { Community/civic activities } & & \text { Proprietary Research }\end{array}$

This section is your plan for what tactics you are most interested in developing and utilizing for yourself in the next few years (which ones are most likely to help you reach your goals). Be as specific as possible. Other tactics may not be appropriate for the near term but you could envision yourself becoming involved in these as you develop further in your career. Put these down so that you can be thinking and planning how to execute your long term goals.

\section{Qualification Packages}

The qualification package, key to winning new clients (Taylor, 2008), is distributed to prospects and would be considered part of instructional materials. More than a brochure, a qualification package is a firm publication or booklet that is part of its broader integrated communication and business development program. It is distributed to prospective clients and includes such items as scope of services, key personnel bios and photos, firm mission statement, brand promise, value propositions, areas of specialization, notable clients in industries served, key differentiators and success stories. Key differentiators for accounting professionals include global strengths, the value of services, fee structure, accessibility of key accounting professionals and overall responsiveness. The purpose of the qualification package is to move a firm toward the next phase in acquiring new clients, the RFP. Basically, the qualification package is a description of the firm in terms of professional qualifications. Professional service firms customize these packages to the prospective client, thereby delivering a message based on individual needs. Integration with the professional service firm's website communications is critical as to present a coherent and consistent message to prospective clients.

In our class each team is required to develop a qualification package for their firm. Table 5 contains additional information regarding a qualification package and can be used as an assignment. An effective package should draw on the marketing concepts presented in class as well as incorporate participants own personal marketing plans developed earlier in the course. Key informants provided examples of qualification packages, which typically exceeded 25 pages before appendices. Student groups prepared qualification packages of similar depth. 
Stages one and two focus on marketing concepts needed by public accounting professionals. The purpose of stage three is to apply these concepts. Participants will need to apply and exhibit technical accounting skills while sharpening and developing their interpersonal competencies. In short, the next stage serves as a platform to integrate marketing and accounting skills.

Table 5: Qualification Package

Each team should form an accounting firm and prepare a qualification packet. Qualification packages function as an introduction to potential clients and include basic information about the firm, such as areas of specialization, key clients, and other success stories. Its purpose is to move a firm toward the next phase in the bidding process, the Request for Proposal (RFP). The qualification package precedes the actual proposal.

While you are free to put together whatever you wish (in fact you should be creative), one study identified the following possible components:

Taylor, Ann "Qualifications that Break Away from the Pack: Essentials of Differentiation" White Paper, Society for Marketing Professional Services Foundation, (2008), p. 13.

\begin{tabular}{|l|c|}
\hline \multicolumn{1}{|c|}{ Component } & Included in Documents Reviewed \\
\hline Scope of Services & $90 \%$ \\
\hline Firm Overview & $87 \%$ \\
\hline Contact Information & $80 \%$ \\
\hline Case Studies & $78 \%$ \\
\hline Year of Founding/Incorporation & $77 \%$ \\
\hline Principals' Biographies & $58 \%$ \\
\hline Number of Employees & $57 \%$ \\
\hline Philosophy & $41 \%$ \\
\hline References & $41 \%$ \\
\hline Organizational Chart & $36 \%$ \\
\hline Awards & $35 \%$ \\
\hline Principals' Photographs & $33 \%$ \\
\hline Mission Statement & $22 \%$ \\
\hline Annual Revenue & $19 \%$ \\
\hline
\end{tabular}

Hints:

1. Make sure content is ordered logically as it is critical in determining readability and overall communication effectiveness.

2. Do not overwhelm the reader with details. Use bullet points, figures and facts to build details of the firm.

3. Use photography (especially of key personnel), illustrate with compelling stories and, where possible, validate claims with independent support. Remember the role of vivid information.

4. Differentiate your firm and reinforce your branding (mission, branding, positioning, value proposition and overall strategic marketing philosophy) using the tools we have been learning in class. Your bios can be based on your personnel marketing plans.

5. Qualification packages should also convey the same reasoning the firm intends to use when it pitches itself to the prospective client after making the RFP list. Consistency throughout the selection process is critical to maintaining a clear message and reassures the client that the firm is qualified for the task.

\section{Stage Three - Responding to Proposals}

\section{Presentation and Interpersonal Skills}

Depending on the strength of a referral, new clients may not require a proposal. Regardless of the need for a proposal, the accounting professional must understand the decision maker(s), recognize criteria for firm selection and demonstrate an understanding of the potential client's business. Critical factors used by a client to select an accounting firm include personal integrity of the accounting professional, technical and industry expertise, size of the firm, recommendations by other trusted professionals, and the commitment to return phone calls (Stanny, Anderson, \& Nowak, 2000). 
Table 6: Client Acceptance Form

Prepared by Date form completed

Information about potential client:

\begin{tabular}{|l|l|}
\hline Name & Location (city, state) \\
\hline Owners or key management personnel & Attorney \\
\hline
\end{tabular}

Financial condition:

Stron

Moderate

Weak

Requested services (check all that apply):

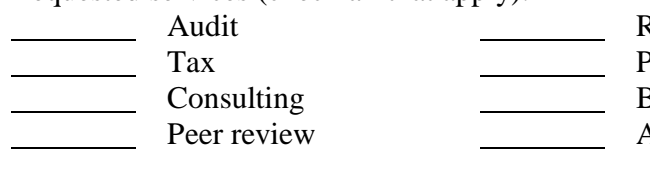

Review

Pension admin

Bus valuation

Agreed-upon procedures
Compilation

Atg software

Payroll

Other (explain)

Billing information:

Expected annual billings Up to $\$ 10,000$

$\overline{\text { Expected realization }}$ Less than $80 \%$

$\$ 10,000$ to $\$ 50,000$

$80 \%$ to $90 \%$
Over $\$ 50,000$

$90 \%$ to $100 \%$

Engagement risks:

1. Independence problems or conflict of interest

2. Management integrity issues

3. Collection problems

4. Lack of professional expertise to perform engagement

5. Staffing commitment beyond our capabilities (busy season)

6. Are there disagreements with present accounting firm?

7. Is there anything about the engagement that subjects us to undue liability exposure, particularly to third parties, or causes us to be uncomfortable about being associated with the client?

Other relevant matters:

Engagement partner

Concurring partner

Date

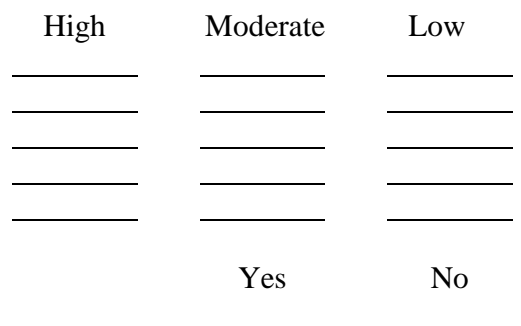

Understanding the potential client's business involves a review of its financial statements, an understanding of the industry in which it operates, identification of its service needs, assessment of management's integrity, evaluation of potential liabilities to third parties, and knowledge of its relationship with past and present accounting firms. An assignment separate from the RFP, to help participants learn these research skills, is available by contacting an author. For an example client acceptance form, see Table 6.

To apply the concepts of the course, a request for proposal was prepared by the authors and was largely based on materials from the American Institute of Certified Public Accountants (AICPA, 2005). The AICPA suggests that RFPs contain background information about the organization requesting accounting services. In addition, a request letter needs to describe the desired services and list the key personnel at the requesting organization. The requesting organization typically explains the nature of the relationship with the prior accounting service provider and any other information relevant to proposing. In order for the requesting organization to make a well-informed decision, the organization needs to provide a detailed list of information requested from the proposing 
firm. Furthermore, a RFP should describe how proposals will be evaluated. See Table 7 for an example RFP from the American Red Cross. Other RFPs could be developed. Importantly, Table 8 gives an overview of assignments used to help students develop their response to the proposal, as well as grading criteria.

Griffin (2009) lists seven elements of a strong proposal, and these can be presented to help participants with the written portion of the proposal. Exposure to the basics of personal selling and the importance of asking for the sale are also necessary for participants to write and present a winning proposal. Closing the deal demonstrates technical expertise and also the ability to quickly establish trust and share a client focus. Many accountants have difficulty with closing techniques because selling accounting services is unfamiliar to them (Wolosky, 2006).

\title{
Estimating Fees
}

Part of the process of responding to an RFP involves estimating fees for services. Table 2 reflects such fees in the first line item, gross fees earned. Fees represent the primary source of revenue for an accounting firm and are critical when determining the net amount remaining for owners. Estimating fees is a complex process for most accounting firms because it reflects the growth strategies of a firm. We asked participants to consider fee-based pricing, which is quantified using the number of hours needed to provide the service, compared to value-based pricing, which reflects the client's perceived worth of the service. Contingency fees are often excluded from consideration as they impair independence of an accounting firm. Participants need awareness that clients seek cost efficiencies in all areas of their organizations, including accounting fees (Reason, 2010).

Table 7: Example Request for Proposal

\author{
Managing Partner \\ CPA Firm \\ Street Address \\ City, State, Zip
}

Dear Sir or Madam:

Our organization is accepting proposals from CPA firms to provide audit and tax services for our organization in the future. We invite your firm to submit a proposal to us by and other pertinent information follows: , for consideration. A description of our organization, the services needed,

\section{Background of the American National Red Cross}

The American National Red Cross (Organization) is a 501(c) (3) public charity headquartered in Washington, which relies upon the support of generous Americans to fulfill its mission. The Organization has national and international programs that are conducted by its headquarters, biomedical services, and chartered local chapters. Annual revenues exceed $\$ 3$ billion each year, and the Organization employs more than 23,000 people. In addition, approximately 1.4 million volunteers donate time for the Organization's causes. The Organization has a June 30 fiscal year end, with a requirement to file an audited financial statement with the bank by September 30 of each year. Because the Organization consists of its people, the audited financial statements will also be made available to the public through our website.

\section{Services to Be Performed}

Your proposal is expected to cover the following services:

1. Annual audit to be completed in compliance with the above filing requirement and meetings with Audit and Risk Management Committee and or Board of Directors, as necessary.

2. Tax filings for the Organization and related foundation.

\section{Key Personnel}

Following are key contacts for information you may seek in preparing your proposal...

Requests for additional information, visits to our sites, review of prior financial statements and tax returns, and/or appointments with the executive director or chief financial officer should be coordinated through our controller. You may reach him at the number listed above. Please return the completed proposal to my attention at the above address by 
Table 7 cont.

Most Recent Financial Statements and Form 990

These items are available on our website www.redcross.org.

\section{Relationship with Prior CPA Service Provider}

These services have been provided by KPMG, LLP. In preparing your proposal, be advised that management will give permission to contact prior auditors. The decision to change auditors is the result of a periodic review of the Organization's satisfaction with the services.

\section{Your Response to This Request for Proposal}

Please provide the following information:

1. Briefly describe your firm's structure, size and methods of operations, including your firm's worldwide structure, capability and locations. Also describe how your firm's structure, size and methods would benefit our organization.

2. Detail your firm's experience in providing auditing and tax services to companies in the not-for-profit sector, as well as associations of a comparable size to the American National Red Cross.

3. Discuss the firm's independence with respect to the American National Red Cross.

4. Discuss commitments you will make to staff continuity, including your staff turnover experience in the last three years.

5. Identify the five largest clients your firm (or office) has lost in the past three years. Without violating client confidentiality, please indicate the reasons for such losses. Also discuss, in instances where loss of the client was due to an unresolved auditing or accounting matter, the process of attempting to resolve the issue(s).

6. Identify the partner, manager, and in-charge accountant who will be assigned to our job if you are successful in your bid, and provide biographies. Indicate any complaints against them that have been leveled by the state board of accountancy or other regulatory authority, if any. Indicate any corrective actions that have been taken by the firm with respect to these people.

7. Describe how your firm will approach the audit of the American National Red Cross, including the use of any association or affiliate member firm personnel and the areas that will receive primary emphasis. Also discuss the firm's use of technology in the audit. And finally, discuss the communication process used by the firm to discuss issues with management, the Audit and Risk Management Committee, and the Board of Directors.

8. Set forth your fee proposal for the 2010 audit, with whatever guarantees can be given regarding increases in future years. Provide your proposed fee for tax return preparation.

9. Furnish standard billing rates for classes of professional personnel for each of the last three years.

10. Provide the names and contact information for other, similarly sized clients of the partner and manager that will be assigned to our organization for reference purposes.

11. Describe how and why your firm is different from other firms being considered, and why our selection of your firm as our independent accountants is the best decision we could make.

12. Outline your proposed timetable for completing the fiscal 2010 engagement.

13. Broadly discuss any significant issues stemming from recent PCAOB or peer review audits of your firm's procedures, practices or policies.

14. Describe your firm's process to solicit feedback from the client as to firm performance.

15. Describe your views as to the important issues and risks that our organization will need to consider over the next three years and explain how your firm plans to address them.

\section{Evaluation of Proposals}

The American National Red Cross will evaluate proposals on a qualitative basis. This includes our review of the firm's peer review report and related materials, interviews with senior engagement personnel to be assigned to our organization, results of discussions with other clients, and the firm's completeness and timeliness in its response to us.

Please prepare a proposal to be presented on We would also appreciate a response if you decline to submit a proposal.

Sincerely,

Chief Financial Officer 
Table 8: Guidelines for a Customer-Focused Proposal

\section{PURPOSE}

The purpose is to prepare a group presentation in response to a Request for Proposal (RFP). The RFP was issued to your firm by the American Red Cross (ARC).

\section{CLIENT ACCEPTANCE FORM}

The goal of this portion of the case is to discover the nature of the potential client. Start by using the Library Reference Guide to conduct research about the general background of ARC. Complete the Client Acceptance Form as a group. Then, expand your findings as a group to gain a more in-depth knowledge of how ARC functions. At a minimum, read through the three most recent sets of financial statements and corresponding notes. Dig deeper into other information available on ARC's website and other online sources. A minimum of six citations in addition to the ARC website are required to complete this portion of the case.

\section{QUESTIONS FOR KEY PERSONNEL}

According to the top of the second page of the RFP, you may contact the executive director or chief financial officer of ARC with questions and requests for additional information. As this is not feasible in a classroom setting, document your firm's questions in writing for submission. Include answers to your firm's questions to reflect the assumptions your firm will be making during its proposal. As these questions and answers reflect your firm's customer focus, this is a critical aspect of the case study. These questions should be an extension of the research conducted to complete the client evaluation.

\section{WRITTEN PROPOSAL}

Your firm is required to prepare a written proposal in response to the RFP issued by the American Red Cross on The proposal should address each of the 15 response items described in the RFP. Responses to items 12 and 13 are not required due to the classroom setting of this case study. Items 12 and 13 are included to give an idea of what a complete RFP requires. Some items will require research to identify realistic information in the written proposal. Other items may require that assumptions be made. When possible, conduct research to include realistic information. Sources need to be cited throughout the written proposal.

In addition, see the grading criteria for the written proposal on a subsequent page of these directions. Please note that fees need to be addressed in the written proposal. The tax services requested by ARC are expected to require 1,200 professional hours to complete. Additionally, the audit services requested by ARC are expected to require 6,000 professional hours to complete.

An appropriate length for the proposal is between 15 and 25 pages. Appendices, if any, would be provided in addition to the 15 to 25 pages of content. A real-life proposal from Deloitte is available electronically in Sakai for your reference.

\section{PRESENTATION}

Your firm's presentation will be given to the Audit and Risk Management Committee of the American National Red Cross. Members of the Committee are listed below...

All three firms will compete against one another by giving their proposals during the final exam time, which is . See the attached RFP from the American Red Cross for details.

\section{$\underline{\text { GRADING }}$}

In addition to the points possible for the client acceptance form, questions for key personnel, written proposal and presentation, the chosen firm earns _ _ points. The runner up earns _ points. The third place firm earns _ points.

The four evaluative criteria used for the written proposal are described below. Note that the numbered questions below represent a guideline of minimum information to include. __ points may be earned by addressing each of the evaluative criteria.

A. Is it compliant?

1. Does the proposal, as represented by headings and subheadings follow all customer instructions?

2. Does the proposal represent all the customer's requirements regarding the offer?

3. Does it adhere to all customer instructions regarding page limitations, graphics, appearance, etc.?

4. Is the proposal free of spelling errors, excessive jargon and wordiness?

5. Are the visuals and or graphics appropriate and do they communicate their main message effectively? 
Table 8 cont.
B. Is it responsive (customer focused)?
1. Does it address the customer's key issues, concerns, needs, and values in addition to the stated requirements?
2. Does it demonstrate customer focus rather than self-focus? Does it regularly acknowledge the customer's concerns and mention the customer first wherever possible.
C. Does the proposal sell throughout?
1. Does the proposal supply a compelling value proposition or an essential piece of one?
2. Does the proposal make use of a theme statement or statements which links features and benefits to a customer issue or goal?
3. Does the proposal clearly differentiate from competition? Is the value of that differentiation obvious?
D. Technical Quality
1. Is the scope of work adequately understood by the firm and communicated well to the prospective client in the written proposal?
2. Does the proposal include pricing, which takes into account the number of expected hours required to provide the requested services? Furthermore, is the pricing complete and realistic?

\section{Stage Four - Presentation, Acceptance and Satisfaction}

Stage Four of the course requires participants to present their written proposals to a selection committee, follow up on any open items and describe the process of client satisfaction assessment. The proposal itself should reflect the needs of the client and show evidence that the proposing firm understands relevant quality and satisfaction issues. Two conceptual models can be presented, one on the expectancy-disconfirmation model (Oliver, 1980) and the second on service quality dimensions and their relationship to client satisfaction (Zeithaml, Bitner, \& Gremler, 2009). Guides to giving effective oral presentations may be distributed. After listening and evaluating the presentations, committee members make independent judgments regarding the solutions and provide collective feedback to each group upon selecting the winner. Debriefing is more effective at a later date.

\section{Selection Process}

We recommend the selection committee consist of at least three members. At the onset of the course, the selection criteria for the winning solution should be established and shared with participants. Criteria may include: understanding client needs, addressing questions of the committee, demonstrating knowledge of industry issues, using appealing visuals and presenting in an organized fashion. The selection committee needs an experienced accounting professional with specific industry knowledge relevant to the potential client. Another member of the selection committee should have knowledge of building client relationships. The selection committee needs access to the qualification package, the client acceptance form, questions for key personnel and the written proposal. The winning solution is a judgment call, but is validated when the selection committee is comprised of experts in their field and members who make independent judgments of the proposals using the established criteria. The committee confers to cross validate the results after the presentations are given and before debriefing occurs.

\section{Client Satisfaction and Perceptions of Quality}

The expectancy-disconfirmation model holds that satisfaction is determined by the customer's comparison of what was expected to what is perceived to have been received. Satisfaction occurs when the service has met the customer's needs and expectations. Assessments can also be neutral or indifferent when performance is adequate but not exceptional. Satisfaction is a highly variable, moving and dynamic target influenced by a variety of factors. Of particular note are certain situational conditions (uniqueness of the situation, importance of the project, and complexity of the decision), consideration of the associated risk, stakeholder concerns, and fairness (Zeithaml et al., 1993; Patterson et al., 1997). Price paid also has the potential to impact satisfaction judgments, in effect making satisfaction a reaction to value received. The expectancy-disconfirmation model highlights the importance of managing expectations.

Quality is the evaluation of overall excellence. Perceptions of quality lead to client satisfaction. Parasuraman, Zeithaml and Berry (1988) identified five performance factors that contribute to service quality, then identified them as reliability (accuracy), assurance (trust and confidence), tangibles (physical elements), empathy 
(caring, individualized attention), and responsiveness (willing to react in a timely way). These factors are known as the RATER scale. In professional services, reliability is generally considered to be technical performance and is the most important factor in driving quality and satisfaction. However, technical competence is always expected and is a necessary but not a sufficient performance characteristic to result in satisfaction. The significance of these findings for accountants is that client satisfaction with a firm's services is based upon their perception of the quality of the service they receive measured against what was expected (Simon, 2009).

Measuring client satisfaction is a wasted effort if the firm does not react and use the results to change either their marketing strategy (adjusting expectations) or their performance delivery (operational processes). This approach to client satisfaction should be covered in depth during the time students write their proposals, given that each firm is required to report how they will assess client satisfaction. Measuring and managing client satisfaction represent a significant part of the course, just as it is in practice. Contact one of the authors for an exercise designed to integrate these concepts.

\section{DISCUSSION}

This paper provides an extension to the development of professional service marketing courses in two ways. First, the economic reality of today's accounting environment increasingly demands that new hires (professionals) become involved in marketing the firm and themselves at a much earlier stage in their careers. New accounting professionals are also expected to become active participants in the firm's overall marketing efforts necessitating an understanding of branding and image as well as marketing tactics. Secondly, we recommend that this course be taken within the last year of one's graduate studies (for a professional accountant this would be after an auditing course). Students are expected and required to integrate their technical expertise directly with marketing applications. The emerging need to integrate technical and marketing skills drove the development of this distinctive course.

Experiential learning involves the process of creating knowledge through the transformation of experience (Kobe, 1984). Experiential learning has been shown to be particularly effective at achieving attitudinal change through the acceptance of relevance (Smith \& Van Doran, 2004). Since many accounting students lack significant appreciation for the role of marketing in their careers, the use of a series of readings, applied projects, teamwork and presentations designed to enable participants to market accounting services, as outlined in this paper, is particularly germane.

Course participants were anonymously surveyed up to a year into their careers. These young professionals identified three seminar topics of most importance: the personal marketing plan, the role of a service professional, and how to retain existing clients while securing new clients. In addition, participants expressed appreciation for the importance of building image. Upon completion of the course, students were able to better understand the expectations of their employer and the clients they served.

These students, currently working professionals, shared their observations about marketing tactics. All of their employers visibly participated in community/civic activities and networking opportunities. Students could prepare a personal marketing plan involving similar marketing tactics that aligned with their employer's overall marketing strategy and their personal interests. Students observed that employers are increasing their use of social media and web materials.

Because responding to the request for proposal represented a significant part of the course, the survey included specific questions about the project. Participants thought the experience gave them an opportunity to learn how to work with a team and allowed them to improve their ability to deliver presentations. Additionally, the project prepared students to conduct research about an organization as part of their current professional responsibilities. Students felt comfortable researching the strengths and weaknesses of potential clients. One participant wrote that the experience "...taught me how to create a professional, well-designed, and cohesive promotional document. My writing skills improved due to the project." Another person simply enjoyed working with a team to complete a quality project, which well addressed current issues experienced by a client. 
Participants highly valued taking the seminar and deemed it effective. In particular, the seminar positively impacted participants' abilities to interact with future clients. Content regarding customer satisfaction was especially helpful. One person wrote, "Overall, I thought it was a great course...it helped me define what I wanted out of my career and become a better public speaker...I can speak in front of people with no problem." Furthermore, participants recognized the importance of personal marketing and recommended greater emphasis on that topic. More opportunities to make presentations and brand oneself would be welcome.

\section{CONCLUSION}

This paper provides necessary course materials for effectively preparing students for their future roles as public accounting professionals. This seminar-like course makes explicit to participants that they will be involved in marketing, even though it is not specifically part of their job description. In a professional services firm, successful marketing efforts must be integrated throughout all functions of the organization. Branding, marketing and sales are important success factors for public accounting firms of all sizes and require cross-functional individual and team efforts. New hires aware of this marketing reality are in a better position to thrive professionally.

Students integrate their technical accounting skills into marketing objectives at a graduate level. The course demonstrates that technical competency alone does not guarantee long-term success in the public accounting profession. Participants develop their marketing, interpersonal and communication skills. By formulating a marketing strategy for their own firm and pitching services, participants gain the ability to match their career interests with a firm's market position. This paper shares a fresh approach toward building core competencies (i.e. becoming solution-oriented, collaborating with peers, communicating internally and externally, plus problemsolving) desired by employers of accounting professionals.

\section{AUTHOR INFORMATION}

Donna J. Hill currently teaches Services Marketing, Marketing Research, Retail Management and Professional Services Marketing. Her research has appeared in over 20 journals and is centered on customer satisfaction, customer service, retailing and services marketing. Donna has been a leader of several professional development seminars on services marketing, customer satisfaction and measurement as well as internet \& social media marketing. E-mail: donna@ bumail.bradley.edu (Corresponding author)

Shondra Johnson, CPA, CFE, is an instructor of accounting in the Foster College of Business at Bradley University. She teaches courses about international accounting issues, how to conduct interviews in the accounting profession and fraud. Shondra has given presentations to the Institute of Internal Auditors and the Illinois CPA Society. She has management experience with the Big Four. E-mail: sljohnson@bradley.edu

\section{REFERENCES}

1. American Institute of Certified Public Accountants (AICPA). (2011). PCPS CPA firm top issues survey. Retrieved from http://www.aicpa.org/interestareas/privatecompaniespracticesection/ resources/firmstrategyandplanning/pages/pcps\%20top\%20issues\%20survey.aspx

2. (2005). The AICPA audit committee toolkit: Not-for-profit organization. Retrieved from http://www.aicpa.org/interestareas/businessindustryandgovernment/resources/notforprofitresourcecenter/pa ges/aicpanot-for-profitauditcommitteetoolkit.aspx:15-17

3. Andrew, G. G. (2011). Revitalize your firm's marketing strategy. Journal of Accountancy, 212(7), 40-44.

4. Baker, R. J. (2009). Pricing on purpose: How to implement value pricing in your firm. Journal of Accountancy, 207(6), 62-67.

5. Berry, L. L., \& Bendapudi, N. (2003). Clueing in customers. Harvard Business Review, 81(2), 100-106.

6. Berry, L.L., \& Clark, T. (1986). Four ways to make services more tangible. Business, (October-December), 53-54.

7. Bildstein, L. (2010). Retain clients and help them recover. Journal of Accountancy, 209(2), 20-24.

8. Blanchette, D. M. (1996). Marketing education for accountants. Journal of Marketing Education, 18(1), 37 47. 
9. Bonner, P. (2009). Blogging for a better tax practice. Journal of Accountancy, $208,56$.

10. Campbell, T. (2002). Once we had professionals. Consulting to Management, 13(3), 2.

11. Caragher, J. M. (2008). Expand your horizons: Niche marketing success stories. Journal of Accountancy, (April), 56-59.

12. Clow, K. E., \& Kurtz, D. L. (2004). Services marketing ( $2^{\text {nd }}$ ed.). Cincinnati, OH: Atomic Dog Publishing.

13. Drohlich, M. L. (1995). Public relations that works for CPAs. CPA Journal, 65(5), 70-71.

14. Drew, J. (2013). Tackling the top issues. Journal of Accoutancy, 216(3), 24-29.

15. Garikes, R. W., \& Roch, K. K. (2008). The hidden power of client testimonials. Society for Marketing Professional Services Foundation. Retrieved from http://www.smps.org/AM/

Template.cfm?Section=Research\&Template=/CM/ContentDisplay.cfm\&ContentID=2923

16. Gremler, D. D., Hoffman, K. D., Keaveney, S. M., \& Wright, L. K. (2000). Experiential learning exercises in services marketing courses. Journal of Marketing Education, 22(1), 35-44.

17. Griffin, M. P. (2009). How to write a world-class proposal. Strategic Finance, (August), 37-41.

18. Gummesson, E. (1981). The marketing of professional services - 25 propositions. Marketing of Services. Chicago, IL: 108-112.

19. Hill, D.J., \& Gandhi, N. (1992). Services advertising: A frame-work to its effectiveness. The Journal of Services Marketing, 6(4), 63-76.

20. Anonymous. (2009). How to leverage social networking. Journal of Accountancy, 208, 27-29.

21. Kobe, D. A. (1984). Experiential learning: Experience as a source of learning and development. Englewood Cliffs, NJ: Prentice Hall.

22. Kotler, P., Hayes, T., \& Bloom, P. N. (2002). Marketing professional services (2 ${ }^{\text {nd }}$ ed.). Upper Saddle River, NJ: Prentice Hall Press.

23. Latta, J. M. (2004). Professional success. San Carlos, CA: Windrose Press.

24. Lovelock, C., \& Wirtz, J. (2011). Services marketing (7 $7^{\text {th }}$ ed.). Upper Saddle River, NJ: Prentice Hall Press.

25. Lowry, J. R., \& Wrege, W.T. (1996). Is niche marketing suitable for your accounting practice? Journal of Professional Services Marketing, 15(1), 137-146.

26. Louwers, T.J., Pasewark, W. R., \& Typpo, E. W. (1999). Accounting firm internet sites that work (and those that do not). The CPA Journal, March. Retrieved from: http://www.nysscpa.org/cpajournal/1999/0399/dept/cpac399.html

27. Maister, D. H. (1997). True professionalism. New York, NY: The Free Press.

28. Maister, D. H. (1993). Managing the professional service firm. New York, NY: The Free Press.

29. McNeilly, K. M., \& Barr, T. F. (2001). Tailoring a marketing course for a non-marketing audience: A professional services marketing course. Journal of Marketing Education, (23), 152-160.

30. Mittal, B. (1999). The advertising of services: Meeting the challenge of intangibility. Journal of Service Research, 2, 98-116.

31. Oliver, R. L. (1980). A cognitive model of the antecedents and consequences of satisfaction decisions. Journal of Marketing Research, 4, 460-69.

32. Reason, T. (2010). Auditing your auditor. CFO Magazine, (April), 36-42.

33. Parasuraman, A., Zeithaml, V. A., \& Berry, L. L. (1988). SERVQUAL: A multiple-item scale for measuring consumer perceptions of service quality. Journal of Retailing, 64(1), 12-40.

34. Patterson, P. G., Johnson, L. W., \& Spreng, R. A. (1997). Modeling the determinants of customer satisfaction for business-to-business professional services. Academy of Marketing Science Journal, 25(1), 4-17.

35. Pinkston, M. (2009). CPAs embrace twitter. Journal of Accountancy, 208, 30-32.

36. Private Companies Practice Section (AICPA)/Texas Society of Certified Public Accountants. (2008). National MAP Survey.

37. Schultz, M., \& Doerr, J. E. (2009). Professional services marketing. Hoboken, NJ: John Wiley \& Sons, Inc.

38. Shepherd, C. D. (1997). Doing the right things and doing them right: A strategic approach to marketing the accounting firm. Journal of Professional Services Marketing, 15(2), 25-39.

39. Simon, G. L. (2009). Taking charge of your client's satisfaction. Society for Marketing Professional Services Foundation. Retrieved from: http://www.smps.org/AM/

Template.cfm?Section=Research\&Template=/CM/ContentDisplay.cfm\&ContentID=2923

40. Smith, L. W., \& Van Doren, D. C. (2004). The reality-based learning method: a simple method for keeping teaching activities relevant and effective. Journal of Marketing Education, 26(1), 67-74. 
41. Stanny, E., Anderson, S., \& Nowak, L. (2000). Contributing factors in the selection and retention of local accounting firms. National Public Accountant, 45(1), 19-21.

42. Stimpson, J. (2007). Top firms' web sites. The Practical Accountant, 40(1), 32-35.

43. Taylor, A. (2008). Qualifications That break away from the pack: Essentials of differentiation. Society for Marketing Professional Services Foundation.

44. Wisenblit, J. (1994). Services marketing education: a pragmatic paradigm. Journal of Marketing Education, 16(Fall), 45-55.

45. Wolosky, H. W. (2006). Close the deal. The Practical Accountant, (January), 28-33.

46. Young, L. (2005). Marketing the professional services firm. Hoboken, NJ: John Wiley \& Sons, Inc.

47. Zdunich, C. (2010, November). Interview of sales manager. Elk Grove Village, Illinois: Porte Brown LLC.

48. Zeithaml, V. A., Bitner, M. J., \& Gremler, D. D. (2009). Services marketing (5 ${ }^{\text {th }}$ ed.). New York, NY: McGraw-Hill.

49. Zeithaml, V. A., Berry, L. L., \& Parasuraman, A. (1993). The nature and determinants of customer expectations of service. Academy of Marketing Science Journal, 21(1), 1-12.

50. Zenger, T. (2013). What is the Theory of Your Firm? Harvard Business Review, (June), 73-78. 